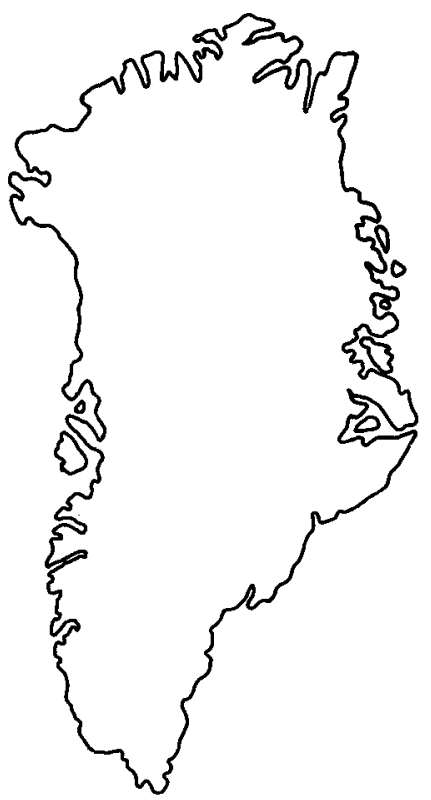

\title{
Silurian thelodont scales from North Greenland
}

\author{
Susan Turner and John S. Peel
}

\begin{abstract}
Thelodont scales are recorded from samples of Silurian limestone from Hall Land, Washington Land and Peary Land, North Greenland. Faunas of probable Early Silurian age compare best with faunas from western Europe, while a fauna of Late Silurian (Pridoli) age from Hall Land can be compared with faunas from Arctic Canada and Tuva. The preoccupied names Logania Gross, 1967 and Katoporus Gross, 1967 are replaced by Loganella and Katoporodus, respectively.

S. T., Queensland Museum, South Brisbane, Queensland, P.O. Box 300, Australia 4101.

J. S. P., Grønlands Geologiske Undersøgelse, Øster Voldgade 10, DK-1350 København K, Denmark.
\end{abstract}

Vertebrate remains are rare in the Lower Palaeozoic of Greenland. The Lower Ordovician of East Greenland has yielded fragments of Anatolepis, originally described as a vertebrate from Svalbard by Bockelie \& Fortey (1976), but subsequent authors are divided as to the real affinities of the material (see discussion in Peel, 1979; Briggs \& Fortey, 1981; Thompson \& Plotnick, 1981). Undoubted vertebrates are first known from the Lower Silurian of western North Greenland where Norford (1972) reported anaspid fragments from western Hall Land (fig. 1). Bendix-Almgreen, this report, also describes vertebrate fragments from Silurian (Wenlock-Ludlow boundary) strata in Washington Land. In 1974 Bendix-Almgreen \& Peel recorded abundant vertebrate remains in latest Silurian or possibly earliest Devonian strata in western Hall Land. Acanthodian scales and tooth-whorls were most conspicuous but heterostracan and thelodont remains were also well represented. Examples of the fauna were illustrated by Bendix-Almgreen (1976) in his summary of palaeovertebrate faunas from Greenland. He referred thelodont scales to Thelodus trilobatus and Logania spp., cf. kummerowi and L. scotica.

This paper describes the thelodont scales from the samples examined by Bendix-Almgreen \& Peel (1974) and Bendix-Almgreen (1976) from near Halls Grav (= Hall's grave), western Hall Land (fig. 1). Subsequent preparation of further samples from the same locality has provided additional material. Representative specimens are illustrated.

In addition, thelodont remains are recorded from older Silurian strata at two other localities in Hall Land, and from one locality each in Washington Land and Peary Land (fig. 1). Some of this additional material was obtained from GGU samples processed for conodonts by R. J. Aldridge and H. A. Armstrong (University of Nottingham). All specimens were recovered by digestion of marine limestones in weak acetic acid.

The thelodont scales are, in the main, well preserved and only those from GGU sample 


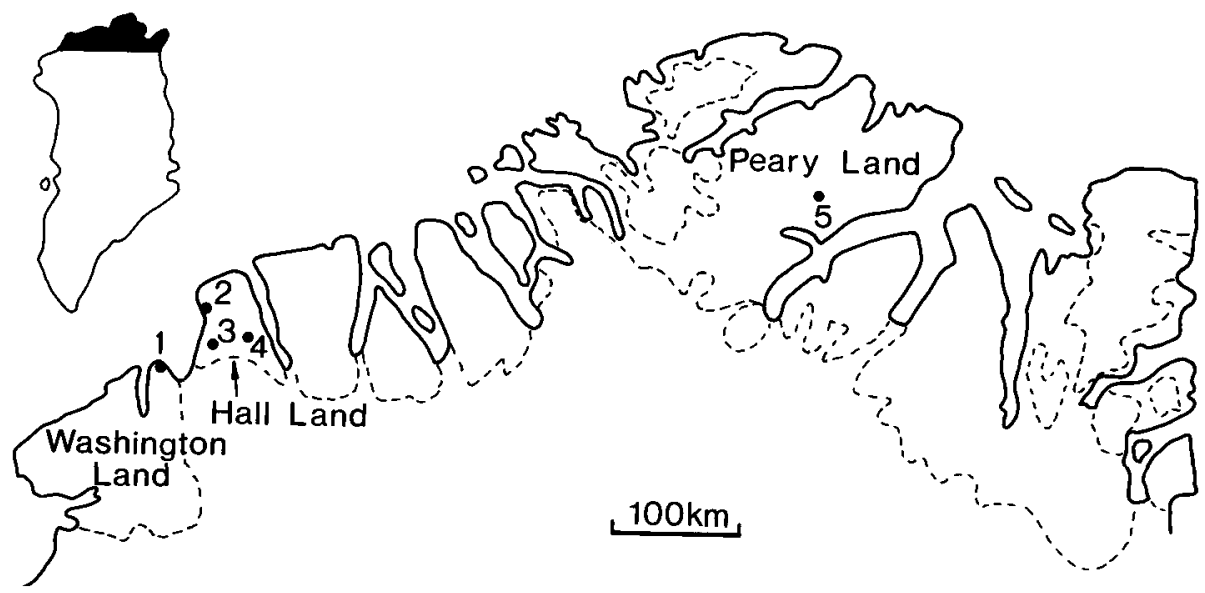

Fig. 1. Thelodont localities in North Greenland. Locality 1, Kap Lucie Marie; 2, Halls Grav; 3, 'Sunmark Mountain'; 4, Kayser Bjerg; 5, central Peary Land.

242841 show signs of etching or wear, being mostly immature, fragile scales. Scale colour varies from dark brown and black to light grey.

\section{New generic names}

In the following discussion two new generic names are introduced to replace preoccupied names. Loganella is proposed to replace Logania Gross, 1967 which is preoccupied by the lepidopteran Logania Distant, 1884 (see Whitley, 1976). Katoporus Gross, 1967 is preoccupied by the insect Katoporus John, 1956 (see also Whitley, 1976) and the new name $\mathrm{Ka}$ toporodus is here proposed as a replacement name.

\section{Thelodont scales from Kayser Bjerg and 'Sunmark Mountain', Hall Land}

Two samples from Hall Land, GGU 82543 from 'Sunmark Mountain' and GGU 82679 from Kayser Bjerg, have yielded thelodont scales during routine conodont preparation (fig. 1). The samples were collected by P. R. Dawes and the late J. H. Allaart (GGU) and are both derived from the Lafayette Bugt Formation of the Peary Land Group (Hurst, 1980; Hurst \& Surlyk, 1982).

Dawes \& Peel (1984) noted that GGU sample 82679 was collected from dark weathering platy limestones and shales at Kayser Bjerg. The age of the sequence is problematic. Brachiopods suggest a probable Ludlow age (A. J. Boucot and J. M. Hurst in Dawes \& Peel, 1984) while graptolites from juxtaposed shales indicate Late Llandovery - Early Wenlock ages (W. B. N. Berry in Dawes \& Peel, 1984). The latter age seems to be confirmed also by conodonts (R. J. Aldridge in Dawes \& Peel, 1984). Dawes \& Peel (1984) could not clarify the age discrepancies between the different faunal elements, but noted comments by J. M. Hurst concerning the anomalous age ranges of brachiopods in the Silurian of North Greenland. 
GGU sample 82543 was collected from the south-west flanks of 'Sunmark Mountain' (fig. 1) from a sequence of dark, thin-bedded, platy limestones and shales, with thin beds of limestone and limestone conglomerate. As with GGU sample 82679 above, evidence from brachiopods suggests a possible Ludlow age, while graptolites and conodonts favour the Llandovery-Wenlock boundary (see discussion in Dawes \& Peel, 1984).

The balance of available evidence seems to suggest that the age of the two samples approximates to the Llandovery-Wenlock boundary.

Most of the thelodont scales in these samples belong to the group based upon the genus Logania which was erected by Gross (1967) to include scales with a modified orthodentine structure in which the pulp cavity is reduced and swings backward into the crown from the central or posterior part of the base. Dentine tubules, especially those from the front half of the crown, lead into dentine canals which can open directly onto the base. The young (immature), wide open pulp cavity develops into a slit leading to the posteriorly placed pulp opening. In older (mature) scales, the pulp opening can be totally obscured by overgrowth of basal tissue. This group of thelodonts includes complete specimens from Scotland, originally named Thelodus scoticus by Traquair (1898) and Thelodus taiti by Stetson (1931). As noted above, the genus name erected by Gross is preoccupied and the new name Loganella is proposed here.

The Greenland scales from GGU sample 82543, and also GGU sample 242841 discussed below, most closely resemble the scale form range exhibited in Loganella scotica (see Traquair, 1899; Gross, 1967; A. Ritchie and S. Turner, unpublished observation) which is known from the Upper Llandovery of Scotland and England (e.g. Ritchie, 1968a; Aldridge \& Turner, 1975). One scale in sample GGU 82543 is very long and superficially resembles a spine from the thelodont Lanarkia, only known from the Upper Silurian of Scotland, and possibly southern Sweden (Lehman, 1937; Turner, 1984). However, the rarity of this type of scale precludes certain evaluation of its relationships. One transparent scale has a pulp canal which can be seen extending to the tip of the crown from a large basal cavity. The base possesses a small anterior down-turned process, not uncommon in some other species of Loganella (see Gross, 1967; Karatajute-Talimaa, 1978). One broken scale from the same sample appears to be a scale of Phlebolepis; it is covered with very fine striations and exhibits numerous posterior denticulations. Phlebolepis has been reported from the early Silurian of Arctic Canada (Thorsteinsson, 1967; Turner, 1976). It is known primarily from complete specimens at Saaremaa (Ritchie, 1968b; Märss, 1979) and from scales in other parts of the USSR (Karatajute-Talimaa, 1978; T. Märss, personal communication).

The loganellid scales in GGU 82679 (fig. 2A-D) may include representatives of a new species. Similar scales are found in Ludlow samples from southern Norway. One or two scales resemble those of Loganella kummerowi (Gross, 1967). There are also head scales of Loganella cruciformis-type, thought to be the head scales of Loganella cuneata (Gross, 1967). This scale form is also known in the Lower Silurian of Siberia (Karatajute-Talimaa, 1978).

\section{Late Silurian thelodont scales from Halls Grav, Hall Land}

GGU samples $82734,82736-8$ are fossiliferous samples collected by Peter R. Dawes and Jan $H$. Allaart (GGU) from a $1 \mathrm{~m}$ thick bed of grey limestone in a sequence of calcareous shales and sandstones assigned to the Chester Bjerg Formation by Hurst \& Surlyk (1982). This formation is one of several comprising the Peary Land Group of Hurst (1980), an es- 
sentially deep-water trough, turbiditic sequence outcropping throughout North Greenland. The limestone bed lies on the eastern side of Observatory Bluff, $2 \mathrm{~km}$ northeast of Halls Grav (fig. 1). The geological setting and associated fauna are reviewed by Dawes \& Peel (1984). Samples from this sequence yield the youngest pre-deformation faunas known from the North Greenland fold belt. Berry et al. (1974) identified graptolites from a slightly lower level as Monograptus sp. of $M$. transgrediens-type, considered to indicate a Late Silurian (Pridoli) age. A single graptolite was identified as Monograptus cf. $M$. aequabilis of earliest Devonian age. This specimen, however, has been redetermined by Jaeger (in Surlyk et al., 1980 ) as being comparable to $M$. transgrediens and, therefore, also of latest Silurian age. Bendix-Almgreen \& Peel (1974) and Bendix-Almgreen (1976) noted the general late Silurian-Devonian aspect of the vertebrate fauna from Halls Grav, and accepted the age assessments based on graptolites.

Bendix-Almgreen \& Peel (1974) reported thelodont scales resembling Thelodus trilobatus and 'Thelodus scoticus' in the samples from Halls Grav. Bendix-Almgreen later (1976, fig. 443) illustrated a scale "reminiscent of Thelodus trilobatus" and identified 'Logania' spp. In 1967 'Logania' kummerowi and 'L.' scotica had been shown by Gross to be equivalent in part to forms he had earlier referred to Thelodus scoticus.

The presence of Thelodus trilobatus and various Loganella scale species in the samples from Halls Grav is confirmed (figs $2 \mathrm{E}, 3 \mathrm{D}, \mathrm{E}$ ). Details of the thelodont faunal composition of the samples are given below:

\author{
GGU sample 82734 \\ Loganella sp. cf. L. tuvaensis \\ Loganella cuneata? \\ Katoporodus sp.
}

GGU sample 82737

Loganella sp. cf. L. tuvaensis

Loganella cuneata

Katoporodus sp.

Goniporus alatus
GGU sample 82736

Loganella sp. cf. L. tuvaensis

Loganella cuneata

Katoporodus sp.

Thelodus trilobatus

Nikolivia sp.

\section{GGU sample 82738}

Loganella sp. cf. L. tuvaensis

Katoporodus sp.

Thelodus trilobatus?

Turinia sp. nov.?

Nikolivia sp.

Scales of Thelodus trilobatus-type (fig. 2E) occur in two of the samples from Halls Grav. These distinctive scales show some variation in size, shape and ornament of the crown. They are rare, however, comprising less than $5 \%$ of the thelodont scales recovered from sample GGU 82738, in which scales of Loganella and Katoporodus (fig. 3A) predominate with over $80 \%$ of the sample. The Thelodus trilobatus scale form is found in Silurian strata and is known from the Late Llandovery to Early Pridoli in Europe and New Brunswick (Turner, 1976, 1984; S. Turner, unpublished observations). The Halls Grav samples may then be the youngest record for this specimen.

Loganellid scales in the Halls Grav samples are comparable with Loganella tuvaensis (Karatajute-Talimaa, 1978). Head, transitional and body scales of this form are present. In the same samples there are also a few scales of Loganella cuneata-type.

The katoporodid scales (fig. 3A,B) include forms typical of the Katoporodus timanicus 


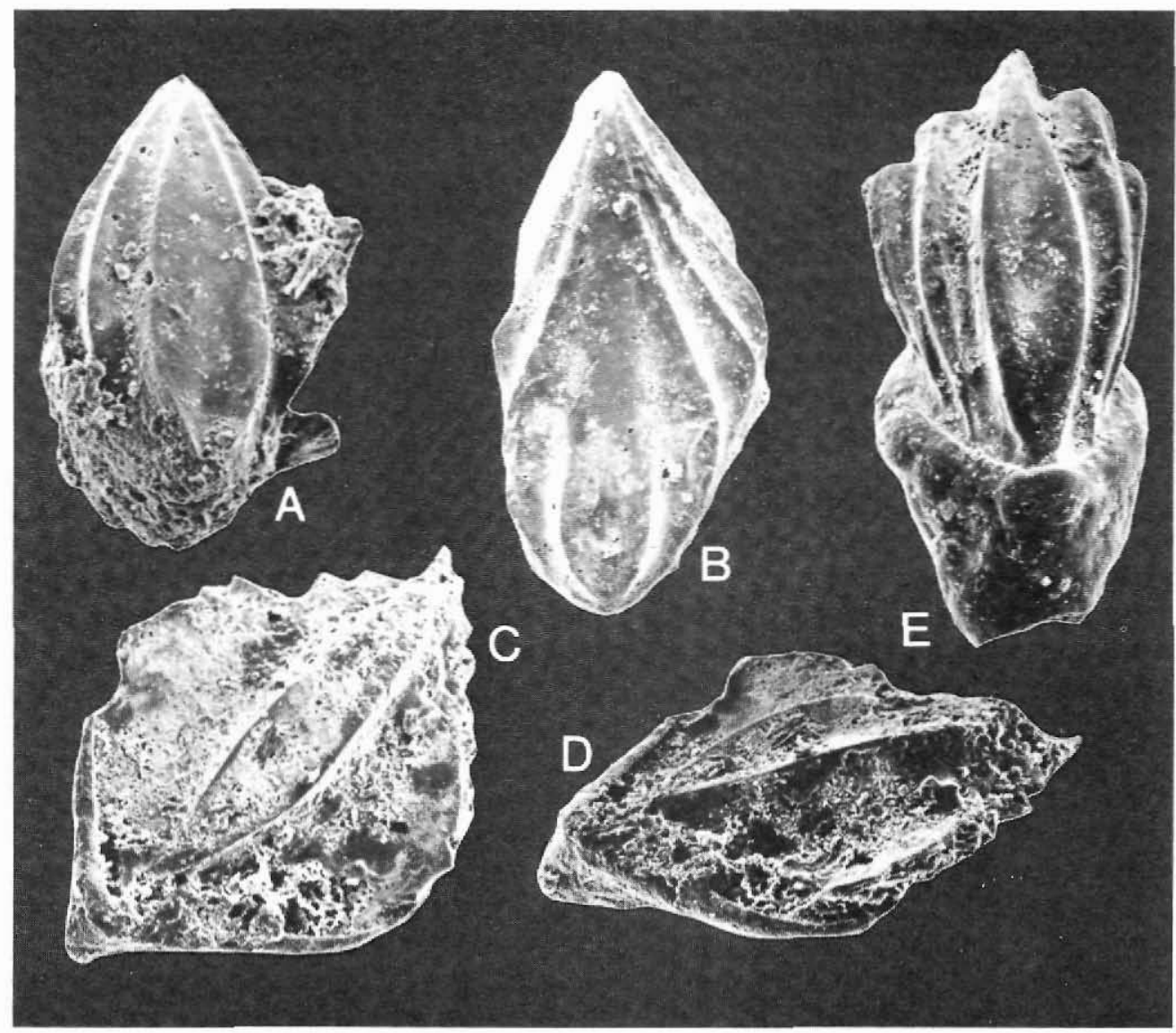

Fig. 2. Thelodont scales from Hall Land. A-D, GGU sample 82679, Lafayette Bugt Formation, Kayser Bjerg. E, GGU sample 82736, Chester Bjerg Formation. A, Loganella cf. L. scotica, body scale MGUH. VP. 3235, × 160; B, Loganella sp. nov., transitional? scale MGUH. VP. 3236, × 110; C, D, Loganella cf. L. kummerowi, body scale MGUH. VP. 3237, × 110; E, Thelodus trilobatus, body scale MGUH. VP. $3238, \times 150$.

morphological series of Karatajute-Talimaa (1978). They resemble forms originally called 'K. grossi' by her in 1970; one or two scales are of the 'K. rhizoides' (Gross, 1967) scale form. This morpho-series is found in the Late Pridoli of Europe. Many of the katoporodid scales are mature with rather deeper bases than is usual.

Rare scales in the Halls Grav samples are different from the three main elements of the fauna. Most intriguing is the presence in two samples of rare nikoliviid scales similar to $\mathrm{Ni}$ kolivia gutta or N. balabayi Karatajute-Talimaa, 1978 (fig. 3C,F). There are also a few scales which probably belong to a new species of Turinia (fig. 4). The crown of these scales is more rounded and wider than in any of the younger Turinia species known elsewhere (e.g. Gross, 1967; Karatajute-Talimaa, 1978; Turner et al., 1981). 


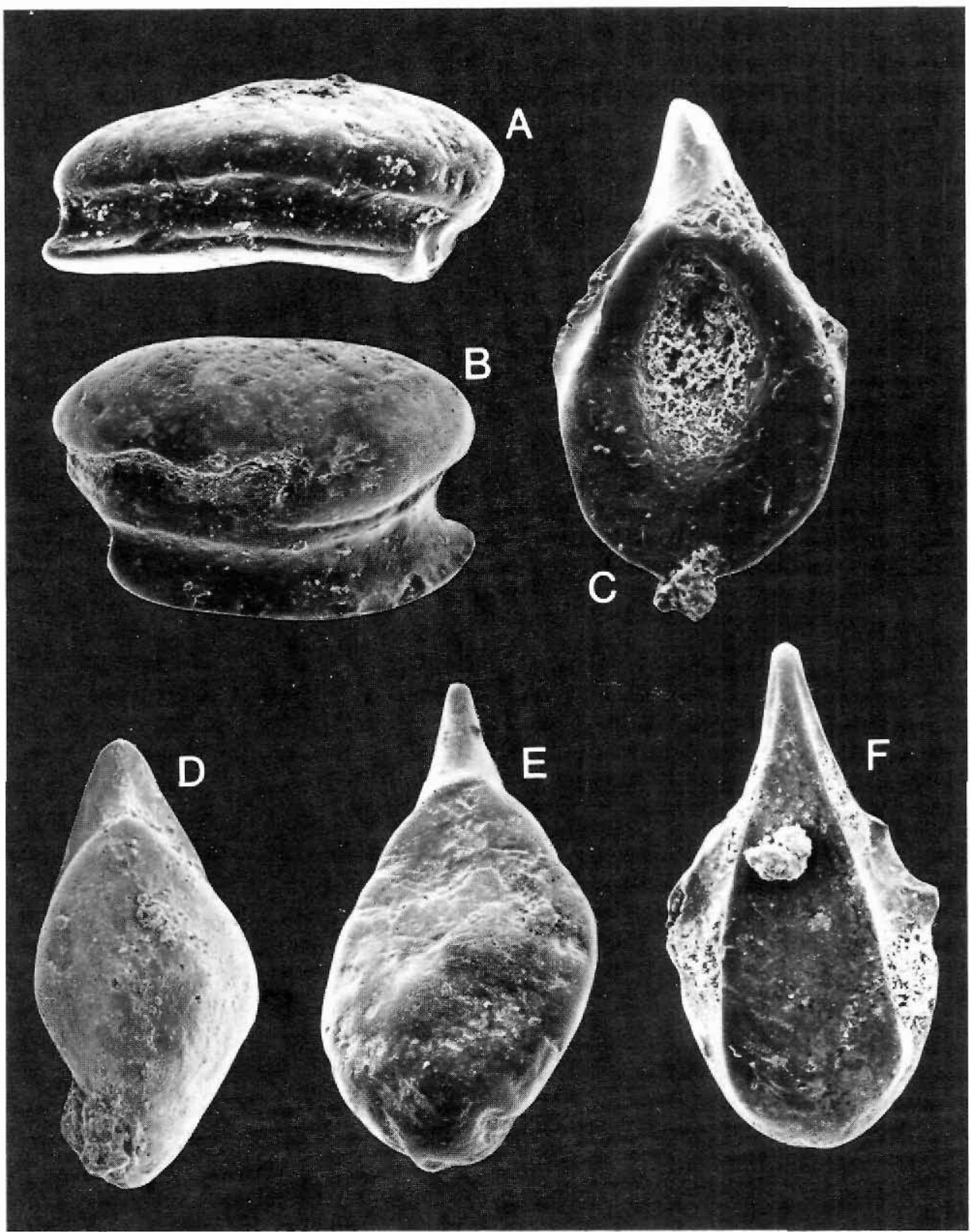

Fig. 3. Thelodont scales from the Chester Bjerg Formation, Halls Grav, Hall Land. A, Katoporodus sp., MGUH. VP. 3239 from GGU sample 82738, × 90; B, Katoporodus sp., MGUH. VP. 3240 from GGU sample 82736, $\times 100$; C, Nikolivia sp., MGUH. VP. 3241 from GGU sample $82738, \times 120$, basal view; D, Loganella cf. L. tuvaensis, MGUH. VP. 3242 from GGU sample 82738, × 100, basal view; E, Loganella cf. L. tuvaensis, MGUH. VP. 3243 from GGU sample $82736, \times 80$, basal view; F, Nikolivia sp., MGUH. VP. 3244 from GGU sample $82736, \times 120$. 


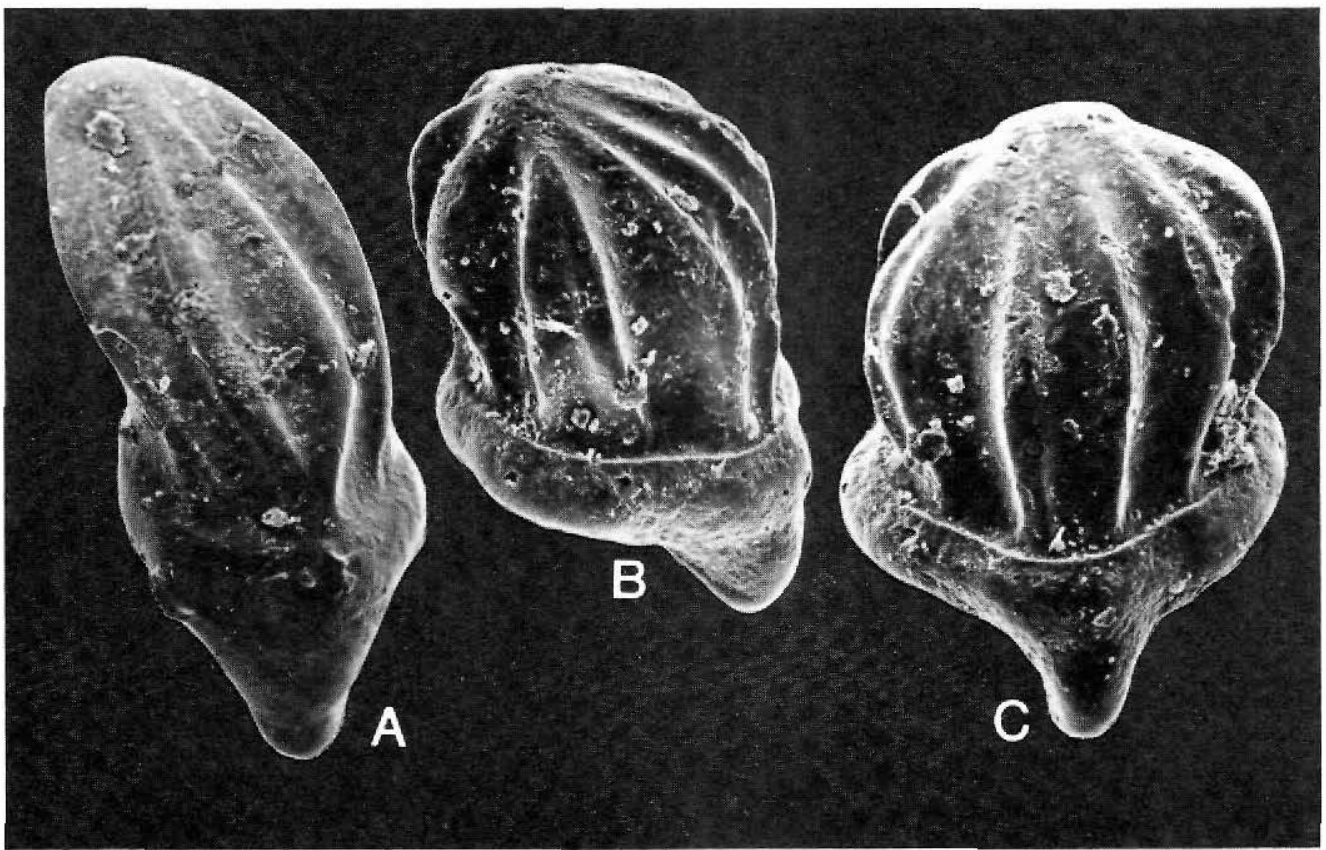

Fig. 4. Scales of Turinia sp. from the Chester Bjerg Formation, Halls Grav, Hall Land. A, MGUH. VP. 3245 from GGU sample 82738, × 125; B,C, MGUH. VP. 3246 from GGU sample 82738, × 200 .

\section{Thelodont scales from Washington Land}

GGU sample 242841 was collected by J. M. Hurst (then GGU) from near the base of the Kap Morton Formation at Kap Lucie Marie, Washington Land (fig. 1). The formation at this locality succeeds the Late Llandovery Kap Lucie Marie Formation but does not itself yield faunas diagnostic of a more precise age than Silurian. Hurst (1980) considered the base of the formation to be diachronous and its age to be Late Llandovery to Wenlock, and possibly younger. GGU 242841 contains rather friable loganellid scales which also resemble those of Loganella scotica. However, the crown ridges of the scales from GGU 82543 from Hall Land are quite pronounced, while the ridges of the Kap Lucie Marie scales are less so. The loganellid scales from this sample do bear a quite deep median anterior crown notch. This feature is also known in Loganella asiatica (Karatajute-Talimaa, 1978) from the Llandovery of Siberia and in some early Wenlock loganellids from southern Norway (Turner, 1984).

\section{Thelodont scale from Peary Land}

GGU sample 228978 was collected by J. E. Mabillard (then University of Nottingham) from a thin, dark limestone bed within the shale-dominated Thors Fjord Member of the Wulff Land Formation of central Peary Land (fig. 1). The unit is a constituent formation of the Peary Land Group and ranges in age from Late Llandovery to Wenlock (Hurst, 1980; Hurst \& Surlyk, 1982). 
Sample GGU 228978 contains one scale which may be a transitional scale of a katoporodid. It is an elongate elliptical scale with a crown smaller than the base and bearing two pairs of posteriorly-directed side notches. The base is slightly convex and in the median line there is a row of small pores which are probably dentine canal openings. This scale is somewhat like the katoporodid scale figured by Aldridge \& Turner (1975) from the Upper Llandovery of the Welsh Borderland. These Early Silurian forms may not belong to the genus 'Katoporus' Gross sensu stricto but as yet there is not enough scale material for a proper study. As noted above, the genus name Katoporus Gross, 1967 is also preoccupied (see Whitley, 1976), and here it is proposed that the new name, Katoporodus, be used in future.

\section{Correlation}

The thelodont faunas from Greenland seem to correspond in general with those known from strata of Early to Late Silurian age in Europe and North America. The older, probably Llandovery, faunas are most like those from Scotland, England and eastern Canada. The Loganella scotica group of scales is typical of Late Llandovery and Early Wenlock in Europe.

GGU sample 82679 contains a fauna not unlike that from the Baltic and possibly Arctic Canada. The loganellid scales are similar to some from the Ludlow of southern Norway (Turner, 1984). The katoporodids appear to occur earlier here than in Europe, although Mark-Kurik \& Noppel (1970) did report them in Saaremaa; they are also common in some Ludlow to Lower Pridoli strata on Somerset Island, Arctic Canada (Turner, 1984).

The Pridoli samples from Halls Grav have thelodont faunas equivalent to those of Europe (e.g. Upper Downton of Welsh Borderland, Turner, 1973; Beyrichienkalk, Gross, 1967; and western USSR and Tuva, Karatajute-Talimaa, 1978) and Arctic Canada (Turner, 1984). Most known Late Pridoli thelodont assemblages are dominated by loganellids and katoporodids. The particular loganellid-katoporodid assemblage represented in the Pridoli samples from Greenland is closest to an undescribed mid-Pridoli fauna found in the Read Bay Formation to Peel Sound Formation succession on Somerset Island by Dr J. Savelle (then University of Ottawa) in 1973 (Turner, 1984).

The few thelodont scales of Thelodus trilobatus which occur are not typical of Late Pridoli elsewhere but usually disappear by the mid-Pridoli; it may be that this species remained longer in Greenland than elsewhere. The occurrence of a turiniid and a nikoliviid (parts of the turiniid assemblage of Turner, 1973) in the Pridoli strata of Greenland might be taken as evidence for the dispersal of these thelodonts from a North American centre into Europe in Late Pridoli times. Vieth (1980) and Dineley \& Loeffler (1976) have described nikoliviid thelodonts from Arctic Canada which may be Late Pridoli in age.

To summarise, the currently described thelodont faunas from Greenland are essentially similar to those of North America and Europe, but elements are present which would be expected in strata of younger or older aspect elsewhere. The Late Silurian samples especially seem to offer us a Pridoli thelodont fauna transitional between that found in North America and that in parts of western Europe and Tuva. The presence of a loganellid-katoporodidturiniid assemblage in Greenland during the Pridoli is of particular interest at a time when thelodonts are apparently absent from Europe (Turner, 1973; Karatajute-Talimaa, 1978; Märss, 1982). 
Acknowledgements. MGUH. VP. indicates the type collection of vertebrates in the Geological Museum, Copenhagen. S. E. Bendix-Almgreen kindly reviewed the manuscript. T. Märss (Institute of Geology, Tallinn) and A. Ritchie (Australian Museum, Sydney) shared information on their current research. S. T. thanks the Director of the Queensland Museum for the use of museum facilities as part of an Honorary Research Fellowship. SEM facilities were provided by the Laboratory of Electron Microscopy of the Geological Central Institute, University of Copenhagen.

\section{References}

Aldridge, R. J. \& Turner, S. 1975: Britain's oldest agnathans. Geol. Mag. 112, 419-420.

Bendix-Almgreen, S. E. 1976: Palaeovertebrate faunas of Greenland. In Escher, A. \& Watt, W. S. (edit.) Geology of Greenland, 537-573. Copenhagen: Geol. Surv. Greenland.

Bendix-Almgreen, S. E. \& Peel, J. S. 1974: Early Devonian vertebrates from Hall Land, North Greenland. Rapp. Grønlands geol. Unders. 65, 13-16.

Berry, W. B. N., Boucot, A. J., Dawes, P. R. \& Peel, J. S. 1974: Late Silurian and Early Devonian graptolites from North Greenland. Rapp. Grønlands geol. Unders. 65, 11-13.

Bockelie, T. G. \& Fortey, R. A. 1976: An early Ordovician vertebrate. Nature 260, 36-38.

Briggs, D. E. G. \& Fortey, R. A. 1981: The cuticle of aglaspidid arthropods, a red-herring in the early history of the vertebrates. Lethaia 15, 25-29.

Dawes, P. R. \& Peel, J. S. 1984: Biostratigraphic reconnaissance in the Lower Palaeozoic of western North Greenland. Rapp. Grønlands geol. Unders. 121, 19-51.

Dineley, D. L. \& Loeffler, E. J. 1976: Ostracoderm faunas of the Delorme and associated Siluro-Devonian formations, North West Territories, Canada. Spec. Pap. Palaeont. 18, 1-218.

Gross, W. 1967: Über Thelodontier-Schuppen. Palaeontographica A, 127, 1-67.

Hurst, J. M. 1980: Silurian stratigraphy and facies distribution in Washington Land and western Hall Land, North Greenland. Bull. Gronlands geol. Unders. 138, 95 pp.

Hurst, J. M. \& Surlyk, F. 1982: Stratigraphy of the Silurian turbidite sequence of North Greenland. Bull. Grønlands geol. Unders. 145, 121 pp.

Karatajute-Talimaa, V. N. 1970: Ichtiofauna dauntona Litvi, Estonii i Severnogo Timana. Paleontologiya i Stratigrafiya Pribaltiki i Byelorussii 11, 33-66. 'Mintis,' Vilnius.

Karatajute-Talimaa, V. N. 1978: Telodonti siluri i devona SSSR i Shpitsbergena, 1-334. 'Mosklas,' Vilnius.

Lehman, J.-P. 1937: Les poissons du Downtonien de la Scanie (Suede). Mem. Fac. Sci. Univ. Paris, Rennes, 1-98.

Mark-Kurik, E. \& Noppel, T. 1970: Additional notes on the distribution of vertebrates in the Silurian of Estonia. Eesti NSV Tead. Akad. Toimetised, Keemia, Geol. 19, 171-173.

Märss, T. 1979: Sistema bokovoi linii ludlovskogo telodonta Phlebolepis elegans Pander. Eesti NSV Tead. Akad. Toimetised, Keemia, Geol. 28, 3, 108-111.

Märss, T. 1982: Vertebrate zones in the East Baltic Silurian. In Kaljo, D. \& Klaaman, E. (edit.) Ecostratigraphy of the East Baltic Silurian. Acad. Nauk Est. SSR Inst. Geol., 97-105. Tallinn: Valgus.

Norford, B. S. 1972: Silurian stratigraphic sections at Kap Tyson, Offley $\varnothing$ and Kap Schuchert, northwestern Greenland. Meddr Grønland 195, 2, $40 \mathrm{pp}$.

Peel, J. S. 1979: Anatolepis from the Early Ordovician of East Greenland - not a fishy tail. Rapp. Grønlands geol. Unders. 91, 111-115.

Ritchie, A. 1968a: New evidence on Jamoytius kerwoodi White, an important ostracoderm from the Silurian of Lanarkshire, Scotland. Palaeontology 11, 1, 21-39.

Ritchie, A. 1968b: Phlebolepis elegans Pander, an Upper Silurian thelodont from Oesel, with remarks on the morphology of thelodonts. In Ørvig, T. (edit.) Current problems of lower vertebrate phylogeny. Proc. Fourth Nobel Symp., 81-88. 
Stetson, H. C. 1931: Studies on the morphology of the heterostraci. J. Geol. 39, 141-154.

Surlyk, F., Hurst, J. M. \& Bjerreskov, M. 1980: First age-diagnostic fossils from the central part of the North Greenland foldbelt. Nature 286, 800-803.

Thompson, D. \& Plotnick, R. E. 1981: Cambrian vertebrates: are they arthropods? Geol. Soc. Amer., abstr. with programs, 1981.

Thorsteinsson, R. 1967: Preliminary note on Silurian and Devonian ostracoderms from Cornwallis and Somerset Islands, Canadian Arctic Archipelago. In J.-P. Lehman (edit.) Problemes actuels de paleontologie: evolution des vertebres. Colloques Int. Cent. Natn. Rech. Scient. 163, 45-47.

Traquair, R. H. 1898: Report of fossil fishes. Summ. Progr. Geol. Surv. (U.K.) 1897, 72-76.

Traquair, R. H. 1899: Report on fossil fish collected by the Geological Survey of Scotland in the Silurian rocks of the south of Scotland. Trans. Roy. Soc. Edinb. 39, 827-864.

Turner, S. 1973: Siluro-Devonian thelodonts from the Welsh Borderland. Jl geol. Soc. London 129, $557-581$.

Turner, S. 1976: Thelodonti (Agnatha). In Westphal, F. (edit.) Fossilium catalogus I: animalia. Pars 122, $1-35$.

Turner, S. 1984: Studies on Palaeozoic Thelodonti (Craniata: Agnatha). Unpubl. Ph.D. thesis, Univ. Newcastle-upon-Tyne.

Turner, S., Jones, P. J. \& Draper, J. J. 1981: Early Devonian thelodonts (Agnatha) from the Toko Syncline, western Queensland, and a review of other Australian discoveries. BMR Jl Austr. Geol. \& Geophys. 6, 51-69.

Vieth, J. 1980: Thelodontier-, Acanthodier- und Elasmobranchier-Schuppen aus dem Unter Devon der Kanadischen Arktis (Agnatha, Pisces). Göttinger Arb. Geol. Palaont. 23, 1-69.

Whitley, G. P. 1976: More fish genera scrutinized. Aust. Zool. 19, 45-50. 